\title{
A Rhizobium leguminosarum gene required for symbiotic nitrogen fixation, melanin synthesis and normal growth on certain growth media
}

\author{
F. K. L. HaWkins, ${ }^{1} \uparrow$ C. KenNEDY ${ }^{2}$ and A. W. B. JohNSTON ${ }^{1 *} \ddagger$ \\ ${ }^{1}$ John Innes Institute, AFRC Institute of Plant Science Research, Colney Lane, Norwich NR4 7UH, UK \\ ${ }^{2}$ AFRC Institute of Plant Science Research, Nitrogen Fixation Laboratory, University of Sussex, Brighton BNI 9RQ, UK
}

(Received 29 November 1990; revised 25 March 1991; accepted 24 April 1991)

\begin{abstract}
The gene $n f r X$ in Azotobacter vinelandii activates transcription of other nif genes in that species. A cosmid containing cloned Rhizobium leguminosarum DNA that corrected the Nif- defect of an $n f r X$ mutant of A. vinelandii was isolated. Following Tn5 transposon mutagenesis of the cosmid in Escherichia coli, mutant derivatives unable to correct the $A$. vinelandii $n f r X$ mutants were obtained in two separate regions of DNA. In addition, mutations close to one of the $n f r X$ regions conferred a complex phenotype when introduced into the Rhizobium genome by marker exchange. These mutants induced non-fixing nodules on peas, were slow-growing on media with succinate as $\mathbf{C}$ source or nitrate as $\mathbf{N}$ source and, when present in $\boldsymbol{R}$. leguminosarum biovar phaseoli, they failed to make melanin, a pigment that is normally synthesized by $R . l$. bv. phaseoli. The mutated gene, termed melC, was fused to uidA (which encodes $\beta$-glucuronidase); it was found that transcription of melC-uidA was enhanced in microaerobic conditions and that it was expressed at high levels in infection threads in pea nodules.
\end{abstract}

\section{Introduction}

Gram-negative soil bacteria known collectively as the 'rhizobia' have the ability to induce and occupy nodules on the roots (and sometimes shoots) of leguminous plants within which the bacteria fix atmospheric $\mathrm{N}_{2}$. The interaction is complex and precise, involving many defined morphological and biochemical changes in both partners. As might be expected, many genes in both participants in the interaction are required for the development of a mature, $\mathrm{N}_{2}$-fixing nodule, and with the bacterial partner, in particular, many of these symbiotic genes have been identified and analysed in some detail (see Long, 1989, for a review).

In the fast-growing genus Rhizobium many but by no means all of the symbiosis-related genes are on large Sym plasmids. In the species $R$. leguminosarum there are three biovars, namely phaseoli, trifolii and viciae. These are defined on the basis of their host-ranges which are, respectively, represented by Phaseolus beans, clover and peas, the host-range determinants being a cluster of genes on the particular Sym plasmid contained in each of these three biovars. Apart from host-range specificity

$\dagger$ Present address: School of Life Sciences, Department of Applied Biology, University of Hull, Hull, UK.

$\ddagger$ Present address: School of Biological Sciences, University of East Anglia, Norwich NR4 7TJ, UK. there are very few features that distinguish these three biovars. One characteristic, though, is that nearly all strains of bv. phaseoli but very few of the other two make the pigment melanin (Johnston et al., 1978; Beynon et al., 1980). It has been shown that at least two genes required for its synthesis are located on the Sym plasmid of $R . l$. bv. phaseoli. Mutations in one of these abolish symbiotic $\mathrm{N}_{2}$ fixation on Phaseolus beans and it was shown that this ' $m e l$ ' gene was in fact the regulatory nif $A$ gene which is also required for the activation of transcription of many nif genes (Borthakur et al., 1987; Hawkins \& Johnston, 1988). A second gene, melA, which is also on the Sym plasmid, is required for melanin synthesis but mutations in melA had no apparent effect on symbiotic $\mathrm{N}_{2}$ fixation (Borthakur et al., 1987). Transcription of melA was activated, under conditions of low oxygen tension, by the regulatory nif $A$ gene of $R$. $l$. bv. phaseoli (Borthakur et al., 1987; Hawkins \& Johnston, 1988); indeed when the cloned $m e l A$ gene was transferred to an Escherichia coli strain containing the cloned nif $A$ gene of the diazotroph Klebsiella pneumoniae, the colonies of $E$. coli were brown (Hawkins \& Johnston, 1988). Though not formally proven, the fact that transfer of $m e l A$ to $E$. coli resulted in melanin production (provided that $n i f A$ was present to activate transcription of $m e l A$ ) suggested that $m e l A$ was the structural gene for tyrosinase, the enzyme that catalyses the conversion of tyrosine to the polymer melanin. 
Given that mutations in melA have no discernible effects on symbiotic $\mathrm{N}_{2}$ fixation under the conditions that we employ in the laboratory, it is clear that melanin synthesis per se is not absolutely required for $\mathrm{N}_{2}$ fixation. However, the fact that the putative gene for tyrosinase is on the Sym plasmid and, more strikingly, that melA is activated by nif $A$, implies that there is a selective advantage to strains of $R$. $l$. bv. phaseoli which possess the ability to make melanin. One possible role is that the 'tyrosinase' in fact acts as a polyphenol oxidase; potentially harmful phenolics, made by the plant as the nodule senesces, may be detoxified due to polymerization mediated by the product of $\mathrm{melA}$.

Having shown that two genes on the Sym plasmid of $R$. $l$. bv. phaseoli were required (and apparently sufficient) for melanin synthesis, we report here the presence of another gene, melC, which is not on the Sym plasmid and which is required, not only for melanin synthesis but also for symbiotic $\mathrm{N}_{2}$ fixation. Further, mutations in melC cause a reduction in growth rate of Rhizobium in certain growth media.

\section{Methods}

Strains and plasmids. Strains of Rhizobium, E. coli, Azotobacter vinelandii and plasmids that were used are shown in Table 1.

Media and general microbiology. Growth media and general culture conditions for growing Rhizobium and E. coli were as in Beringer (1974). $A$. vinelandii was grown on Burk's sucrose medium with (BSN) or without (BS) fixed nitrogen (Newton et al., 1953).

Plasmids were transferred by conjugation as described by Johnston et al. (1978); in some cases the 'helper' plasmid pRK2013 was also present in triparental matings (Figurski \& Helinski, 1979). For conjugational matings between $E$. coli and $A$. vinelandii the latter was present in 10-fold excess.

Melanin production was determined by the method of Johnston et al. (1982). (1987). Cells were grown on TY medium supplemented with L-tyrosine and $\mathrm{CuSO}_{4}$; after $3 \mathrm{~d}$ at $28{ }^{\circ} \mathrm{C}$, cells were lysed by the addition of a drop of $1 \%(w / v)$ SDS.

Peas were inoculated and grown, nodules excised and bacteria isolated as described by Beynon et al. (1980).

$\beta$-Galactosidase activity was assayed according to the method of Miller (1972) as modified by Rossen et al. (1985). $\beta$-Glucuronidase was measured according to Jefferson et al. (1986). Bacteria were grown under controlled $\mathrm{O}_{2}$ tension as described by Hawkins \& Johnston (1988). The units of $\beta$-glucuronidase were calculated in the same way as the Miller units of $\beta$-galactosidase; however, the units obtained were two orders of magnitude less than for $\beta$-galactosidase and therefore the units are presented as $\times 100$.

The transposons $\operatorname{Tn} 5$ and $\operatorname{Tn} 3$ gus (uidA) were used as mutagens. The latter transposon contains a promotorless uidA gene close to one end and retains the ampicillin resistance of the parental $T n 3$. E. coli strains harbouring a chromosomally located copy of either transposon, and containing pIJ1651, were used as donors in triparental crosses with a recipient (either the polA E. coli strain $\mathrm{C} 2110$ or Rhizobium) which cannot support the replication of the helper plasmid pRK2013. Selection was made for the co-transfer of the resistance marker (Tc) of the target plasmid and that ( $\mathrm{Km}$ or Ap) of the transposon. Marker exchange into the Rhizobium genome was as described by Ruvkun \&
Table 1. Strains and plasmids used in this study

\begin{tabular}{|c|c|c|}
\hline $\begin{array}{l}\text { Strain or } \\
\text { plasmid }\end{array}$ & Characteristics & Source \\
\hline \multicolumn{3}{|l|}{ E. coli } \\
\hline 803 & Used for transformation & Wood (1966) \\
\hline $\mathrm{C} 2110$ & $\begin{array}{l}\mathrm{Nal}^{\mathrm{r}} \text {; used as recipient for } \\
\text { transposon mutagenesis }\end{array}$ & Stachel et al. (1985) \\
\hline UNF510 & Contains chromosomal $\mathrm{Tn} 5$ & Merrick et al. (1978) \\
\hline \multicolumn{3}{|l|}{$\begin{array}{l}\text { Rhizobium } \\
\text { leguminosarum }\end{array}$} \\
\hline $\begin{array}{l}4292 \\
8401 \mathrm{pRL} 1 \mathrm{JI}\end{array}$ & $\begin{array}{l}\text { bv. phaseoli wild-type; also nif } \\
\text { bv. viciae wild-type; also str }\end{array}$ & $\begin{array}{l}\text { Lamb et al. }(1982) \\
\text { Downie et al. }(1983)\end{array}$ \\
\hline \multicolumn{3}{|l|}{$\begin{array}{l}\text { Azotobacter } \\
\text { vinelandii }\end{array}$} \\
\hline MV16 & $n f r X, \mathrm{Nif}^{-}$ & Santero et al. (1988) \\
\hline MV17 & $n f r X, \mathrm{Nif}^{-}$ & Santero et al. (1988) \\
\hline MV700 & $n f r X, \mathrm{Nif}^{-}$ & $\begin{array}{l}\text { Toukdarian \& } \\
\text { Kennedy (1986) }\end{array}$ \\
\hline \multicolumn{3}{|l|}{ Plasmids } \\
\hline pRP2JI & R. l. bv. phaseoli Sym plasmid & Lamb et al. (1982) \\
\hline pRLIJI & R. l. bv. viciae Sym plasmid & Johnston et al. (1978) \\
\hline pLAFR1 & Pl group cosmid; Tcr & $\begin{array}{l}\text { Friedman et al. } \\
\text { (1982) }\end{array}$ \\
\hline pKT230 & $\begin{array}{l}\text { Q group cloning vector - } \\
\text { Kan }^{r} \text { Str }^{r}\end{array}$ & $\begin{array}{l}\text { Bagdasarian et al. } \\
(1981)\end{array}$ \\
\hline pPH1JI & $\begin{array}{l}\text { P1 group plasmid used for } \\
\text { marker exchange }-\mathbf{G m}^{r}\end{array}$ & Johnston et al. (1978) \\
\hline pRK2013 & $\begin{array}{l}\text { Used to mobilize plasmids in } \\
\text { triparental crosses }\end{array}$ & $\begin{array}{l}\text { Figurski \& Helinski } \\
\text { (1979) }\end{array}$ \\
\hline pIJ 1553 & $\begin{array}{l}\text { R. l. bv. phaseolinif } A \text { cloned in } \\
\text { pKT } 230\end{array}$ & $\begin{array}{l}\text { Borthakur et al. } \\
\text { (1987) }\end{array}$ \\
\hline plJ1578 & melA in pLAFR 1 & $\begin{array}{l}\text { Borthakur et al. } \\
\text { (1987) }\end{array}$ \\
\hline pIJ1608 & $\begin{array}{l}\text { Cloned melA-lacZ fusion in } \\
\text { pLAFR } 1\end{array}$ & $\begin{array}{l}\text { Borthakur et al. } \\
\text { (1987) }\end{array}$ \\
\hline pIJ1651 & $\begin{array}{l}\text { Contains approx. } 30 \mathrm{~kb} \text { of } \\
\text { DNA including } n f r X \text { and } \\
\text { melC in pLAFR }\end{array}$ & This work \\
\hline pIJ1745 & p1J1651 melC::Tn5 & This work \\
\hline pIJ1758 & p1J1651 melC::uidA & This work \\
\hline pIJ1759 & melC cloned in pKT230 & This work \\
\hline
\end{tabular}

Ausubel (1981) except that pPHIJI was used to eliminate the pLAFR1based plasmid.

DNA manipulations. Transformation, DNA isolation and restriction enzyme digestion were done essentially as described by Maniatis et al. (1982).

Histochemical staining of nodules. Histochemical assays were performed on nodule sections (Jefferson et al., 1987). Nodule sections were cut by hand from unfixed nodules from inoculated plants and fixed in $0.3 \%$ formaldehyde in $10 \mathrm{~mm}$-MES, pH 5.6, 0.3 $\mathrm{M}$-mannitol for $45 \mathrm{~min}$ at room temperature, followed by several washes in $50 \mathrm{mM}-\mathrm{NaH}_{2} \mathrm{PO}_{4}$, $\mathrm{pH} 7 \cdot 0$. All fixatives and substrate solution were introduced into the sections with a brief (approx. $1 \mathrm{~min}$ ) vacuum infiltration.

\section{Results}

\section{Isolation of a plasmid containing $\mathrm{nfr} X$ and melC}

Santero et al. (1988) isolated a mutant derivative MV16 of $A$. vinelandii which failed to fix $\mathrm{N}_{2}$. It was shown that MV16 had a mutation in a gene termed $n f r X$ which 
resulted in the failure of the nifHDK operon to be transcribed; thus $n f r X$ appears to be a positively-acting regulatory gene. MV16 also grew more slowly on medium containing ammonium acetate than the wild-type parent strain VW136. A fast-growing derivative, MV17, retained a $\mathrm{Nif}^{-}$phenotype and had $\mathrm{Tn} 5$ in its original site of insertion.

To test whether there was a functional equivalent to $n f r X$ in the genome of $R$. leguminosarum, recombinant plasmids representing a clone bank of $R . l$. bv. phaseoli (Lamb et al., 1985) comprising fragments of DNA approximately $30 \mathrm{~kb}$ in size cloned in pLAFR 1 were mobilized into $A$. vinelandii strain MV17. Selection was made for $\mathrm{Nif}^{+} \mathrm{Tc}^{r}$ transconjugants. Several such transconjugants were obtained; plasmid DNA was isolated from these, transformed into $E$. coli strain 803 and then remobilized into MV17. In one case the MV17 transconjugants were uniformly $\mathrm{Nif}^{+}$, showing that a plasmid, termed pIJ1651, had been isolated which corrected the $n f r X$ defect (Hawkins, 1989). It was shown by hybridization experiments in which $\mathrm{pIJ} 1651$ was used as a probe to genomic DNA from wild-type $R$. $l$. bv. phaseoli strain 4292 and to DNA from a derivative strain 8401 lacking the Sym plasmid pRP2JI, that pIJ1651 did not contain DNA originating from that Sym plasmid since the patterns of hybridizing fragments were identical for the two strains. Plasmid pIJ1651 was mutagenized with $\operatorname{Tn} 5$ and mutant derivatives which failed to correct the Nif- phenotype of MV17 were screened directly by transferring the mutant plasmids into this strain and identifying any that failed to grow on $\mathrm{N}$-free media. These mutations in PIJ1651 were in two clusters, separated by approximately $25 \mathrm{~kb}$, each being towards the extremities of the cloned DNA (Hawkins, 1989).

In addition to this direct screening for insertions in $n f r X$-like genes in pIJ1651, we sought to determine whether there were other genes on this plasmid that were important for symbiotic $\mathrm{N}_{2}$ fixation. To do this, pIJ1651 was introduced into $E$. coli strain UNF510, which contains a chromosomally located $\mathrm{Tn} 5$, and this strain was used as a donor in a triparental mating with $R$. $l$. bv. phaseoli strain 4292. Selection was made for the joint transfer of $\mathrm{Km}^{\mathrm{r}}(\mathrm{Tn} 5)$ and $\mathrm{Tc}^{\mathrm{r}}$ (pIJ1651). Some 50 such mutant derivatives were isolated and for each, the transposon was introduced by marker exchange into the genome of strain 4292. One mutant was altered in its phenotype compared to the wild-type in that it $(a)$ failed to make melanin on complete TY medium and $(b)$ on minimal $(\mathrm{Y})$ medium was slow-growing as judged by visual assessment, the appearance of colonies being delayed by approximately $1 \mathrm{~d}$. Once grown to full size the colonies had a similar appearance to those of the wildtype, indicating that they were not defective in exopolysaccharide production.
The derivative of pIJ1651 containing this mutation, pIJ1745, was isolated, transformed into $E$. coli and then transferred to $R$. $l$. bv. phaseoli by conjugation. Tn 5 was again introduced into the Rhizobium genome by marker exchange. In all cases examined, the homogenotes were unable to make melanin even after prolonged (12 d) incubation on media supplemented with L-tyrosine plus $\mathrm{CuSO}_{4}$ and following lysis of the cells with SDS. Further, these homogenotes were again slow-growing on minimal $Y$ medium. Both these mutant phenotypes were restored to wild-type by the introduction of pIJ1651 but not by its mutant derivative pIJ1745. Thus it was shown that the unusual phenotype was due to the Tn 5 insertion in a gene located on pIJ1651. Because of the role of this gene in melanin production, it was termed melC.

The Tn5 insertion in pIJ1745 was mapped using $B a m \mathrm{HI}, H$ indIII and EcoRI. The transposon was located in a $6.0 \mathrm{~kb} \mathrm{BamHI}$ fragment. The corresponding nonmutated BamHI fragment was cloned from pIJ1651 into pKT230 to form pIJ1759. Introduction of pIJ1759 into the melC derivative of strain 4292 restored the ability to make melanin and to grow at normal rates. The Tn5 insertion was located approximately $5 \mathrm{~kb}$ downstream of one of the regions of pIJ1651 which had been shown to be required to correct the $n f r X$ mutant MV17 of A. vinelandii (Hawkins, 1989). As might be expected, pIJ1745 when introduced into $A$. vinelandii strain MV17 retained the ability to correct its $\mathrm{Nif}^{-}$defect.

\section{Possible role of melC in melanin production}

It had previously been demonstrated that when the melA gene, which encodes tyrosinase, of $R . l$. bv. phaseoli was introduced into $E$. coli, the colonies made melanin provided that the $E$. coli strain also contained the positively-acting nif $A$ gene which is required to activate transcription of melA (Borthakur et al., 1987; Hawkins \& Johnston, 1988). This had suggested that $m e l A$ and nif $A$ were sufficient for melanin production so it was surprising to us to have identified a third genetic element, not on the Sym plasmid, which was also required for the synthesis of the pigment. This indicated that $E$. coli must have a functional counterpart to melC. We tested two possible roles for melC in melanin synthesis: firstly that it might be involved in the regulation of $m e l A$ and secondly that it might be required for the uptake of $\mathrm{Cu}^{2+}$, a co-factor for tyrosinase.

To test the first hypothesis, plasmid pIJ1608, which contains a melA-lacZ transcriptional fusion, was introduced into $R$. $l$. bv. phaseoli strain 4292 and into 4292 melC::Tn5 and $\beta$-galactosidase activities were measured on cells grown microaerobically; transcription of $\mathrm{melA}$ is enhanced under such conditions (Hawkins \& Johnston, 1988). In both backgrounds $\beta$-galactosidase activities 
Table 2. Effect of copper concentration on the growth and melanin production of mutant melC, wild-type, and multicopy melC strains of $R . l$. bv. phaseoli

\begin{tabular}{|c|c|c|c|c|c|c|}
\hline \multirow{3}{*}{$\begin{array}{c}\mathrm{CuSO}_{4} \\
\text { concn } \\
\left(\mu \mathrm{g} \mathrm{ml} \mathrm{m}^{-1}\right)\end{array}$} & \multicolumn{6}{|c|}{ Rhizobium strain*: } \\
\hline & \multicolumn{2}{|c|}{$\begin{array}{c}4292 m e l C:: \operatorname{Tn} 5 \\
(0)\end{array}$} & \multicolumn{2}{|c|}{$\begin{array}{c}4292 \\
(1)\end{array}$} & \multicolumn{2}{|c|}{$\begin{array}{c}4292 / \mathrm{pIJ} 1651 \\
(5-10)\end{array}$} \\
\hline & Mel $\dagger$ & Growth‡ & Mel & Growth & Mel & Growth \\
\hline 50 & - & + & + & + & + & + \\
\hline 100 & - & + & ++ & + & ++ & + \\
\hline 150 & - & + & +++ & + & +++ & + \\
\hline 200 & - & + & $++t$ & + & $++t$ & + \\
\hline 300 & - & + & +++ & + & +++ & + \\
\hline 400 & - & - & - & - & - & - \\
\hline
\end{tabular}

* The number of copies of the melC gene per cell is shown in parentheses.

$\dagger$ Melanin production was assessed visually following lysis of cells with $1 \%$ SDS. Strains were grown for $3 \mathrm{~d}$ at $28^{\circ} \mathrm{C}$ on TY agar plates supplemented with tyrosine $\left(30 \mathrm{mg} \mathrm{ml}^{-1}\right)$ and $\mathrm{CuSO}_{4}$ at the concentration indicated. The amount of melanization was scored from - for no melanin production, to +++ for extensive melanin production.

¥ Bacterial growth (as judged by the appearance of single colonies) on TY agar plates supplemented with tyrosine $\left(30 \mathrm{mg} \mathrm{ml}^{-1}\right)$ and $\mathrm{CuSO}_{4}$ at the concentration indicated. Bacterial growth was scored as - (no growth) or + (appearance of single colonies after $3 \mathrm{~d}$ incubation at $\left.28^{\circ} \mathrm{C}\right)$.

were approximately 500 units, indicating that $\mathrm{melC}$ does not influence the transcription of $\mathrm{MelA}$.

However, it was shown that over-production of the Rhizobium melA gene product could overcome the $\mathrm{Mel}^{-}$ defect of melC mutant strains. Plasmid pIJ1578 contains the melA gene of $R$. l. bv. phaseoli strain 4292 cloned in pLAFR1. When pIJ1578 was introduced into 4292 melC::Tn5 the transconjugants could make melanin at normal rates. Further, when the nif $A$ gene of $R$. $l$. bv. phaseoli cloned in pKT230 to form pIJ1553 was present in 4292 melC: :Tn5, melanin was again made, owing, presumably, to the hyper-expression of $\mathbf{m e l A}$ due to multi-copy nif $A$ (see Hawkins \& Johnston, 1988).

A second possible explanation for the $\mathrm{Mel}^{-}$phenotype, that $\mathrm{melC}$ is involved in $\mathrm{Cu}^{2+}$ uptake/processing, was examined as follows. If a mutation in melC resulted in reduced $\mathrm{Cu}^{2+}$ uptake, such a mutant might be predicted to exhibit enhanced copper tolerance compared to the wild-type and, conversely, a strain with multicopy melC might be more sensitive. Therefore, wild-type strain 4292 , the melC mutant and 4292/pIJ1651 were each grown on solid TY + L-tyrosine supplemented with $\mathrm{CuSO}_{4}$ at concentrations of $50-400 \mu \mathrm{g} \mathrm{ml}^{-1}$. After $4 \mathrm{~d}$ growth at $28^{\circ} \mathrm{C}$ there was no observable difference among the three different strains with regard to their copper tolerance: in all cases, a concentration of $400 \mu \mathrm{g} \mathrm{ml}^{-1}$ completely inhibited growth (Table 2).
Further, the presence of multi-copy melC did not enhance melanin production relative to the wild-type nor did the higher concentrations of $\mathrm{CuSO}_{4}$ restore to the melC mutant the ability to make melanin. Thus it seems unlikely that the melC mutation affects copper uptake and the biochemical role of melC in melanin synthesis is unknown.

\section{Growth characteristics of the melC mutant}

$R$. l. bv. phaseoli strain 4292 melC::Tn5 was originally identified as being unable to produce melanin and slowgrowing on minimal $(\mathrm{Y})$ medium but not on complete (TY) medium. The basis of slow growth on minimal medium was investigated with different $\mathrm{C}$ and $\mathrm{N}$ sources (succinate and sodium glutamate are the routine $\mathrm{C}$ and $\mathrm{N}$ sources, respectively), added to Y medium. Strains 4292 and 4292 melC: :Tn 5 were grown in liquid TY medium and in liquid $\mathrm{Y}$ medium supplemented with: (a) succinate and sodium glutamate; $(b)$ succinate and ammonium chloride; $(c)$ glucose and sodium glutamate; or $(d)$ glucose and ammonium chloride. The growth rates (measured as $\mathrm{OD}_{600}$ ) of the strains in the various media were determined (Fig. 1). Strain $4292 \mathrm{melC}:$ :Tn 5 had a slower rate of growth than the wild-type strain 4292 when succinate was the sole $C$ source. The growth rates of the wild-type and the melC mutant strains were identical when glucose was the $C$ source or when the bacteria were grown in TY medium.

Having observed a difference in growth rate of the melC mutant strain compared to wild-type, depending on the $\mathrm{C}$ source, the ability of the two strains to utilize different $\mathrm{N}$ sources was then examined. This was done by visual assessment of the appearance of colonies of the two strains on plates of minimal (Y) medium supplemented with either succinate or mannitol as the $\mathrm{C}$ source and with sodium glutamate, ammonium chloride, proline, arginine or sodium nitrate as the $\mathrm{N}$ source. On all media containing succinate as the $\mathrm{C}$ source, the growth of strain $4292 \mathrm{melC}:: \operatorname{Tn} 5$ was delayed compared to that of wild-type strain 4292 . On media containing mannitol as the $\mathrm{C}$ source and sodium glutamate, ammonium chloride, proline or arginine as the $\mathrm{N}$ source, no difference in the growth rate of the two strains was observed. However, the growth of strain 4929 melC: $: \operatorname{Tn} 5$ was delayed compared to the wild-type on minimal medium supplemented with mannitol plus sodium nitrate; this was typified by a 1-2 d delay in the appearance of single colonies for the melC mutant strain.

melC cannot complement an A. vinelandii ntr A mutation

In Rhizobium meliloti, the ntrA gene product, a sigma factor of RNA polymerase, is required for succinate 

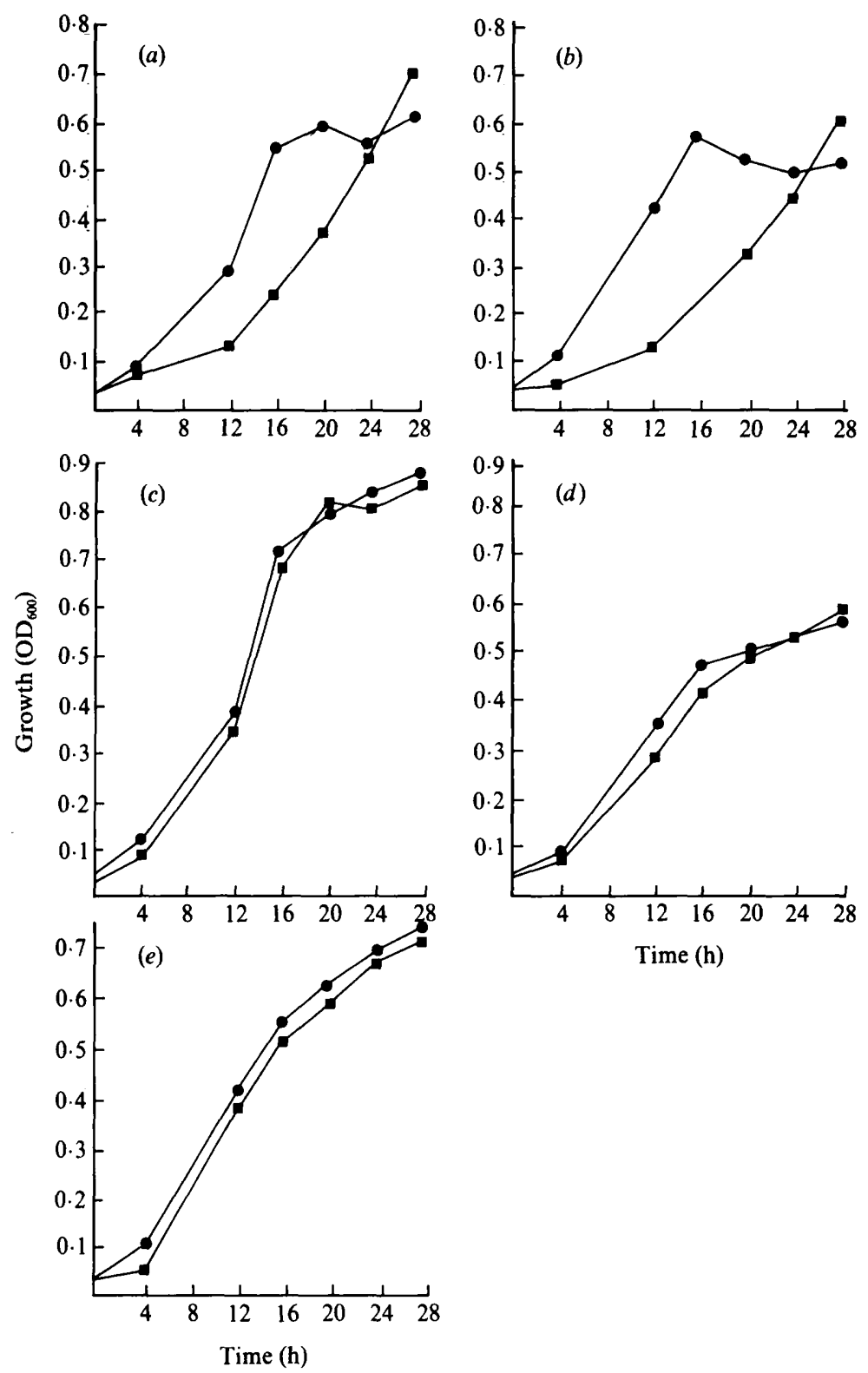

Fig. 1. Growth characteristics of wild-type $R$. $l$. bv. phaseoli (strain 4292) and its melC mutant derivative (strain 4292 melC: : Tn5). Media used: (a) $\mathrm{Y}+$ succinate + sodium glutamate; (b) $\mathrm{Y}+$ succinate $+\mathrm{NH}_{4} \mathrm{Cl}$; (c) $\mathrm{Y}+$ glucose + sodium glutamate; (d) $\mathrm{Y}+$ glucose $+\mathrm{NH}_{4} \mathrm{Cl}$; (e) TY. @, Strain 4292; , strain 4292 melC::Tn5. Each strain was inoculated into $3 \times 100 \mathrm{ml}$ liquid medium, such that initial $\mathrm{OD}_{600}$ values were equivalent and the flasks were incubated, shaking, at $25^{\circ} \mathrm{C}$. The growth rate was monitored by measuring the $\mathrm{OD}_{600}$ at $\mathbf{4 h}$ intervals. Each point represents the mean $\mathrm{OD}_{600}$ value of the three replicates; variation between replicates was less than $5 \%$. transport as well as for nitrate assimilation and symbiotic $\mathrm{N}_{2}$ fixation (Ronson et al., 1987). Mutations in the $R$. $l$. bv. phaseoli melC gene reduced, but did not abolish, the ability to utilize succinate as sole carbon source and nitrate as the sole nitrogen source and (see below) abolished $\mathrm{N}_{2}$ fixation. Thus, the phenotype due to a melC mutation was similar, but not identical, to that of an $n \operatorname{tr} A$ mutant. To test whether melC corresponded to ntrA, pIJ1651, which contains melC, was mobilized into the $\mathrm{Nif}^{-} A$. vinelandii ntrA mutant strain MV700 and the resulting transconjugant was tested for its ability to fix $\mathrm{N}_{2}$. The presence of pIJ1651 did not restore the ability of MV700 to grow on BS, indicating that melC is not functionally equivalent to $n t r A$ of Azotobacter.

\section{Expression of melC and its role in $N_{2}$ fixation}

Transcription of melA, a gene required for melanin production, was shown to be nifA-dependent, and oxygen-sensitive in its activation (Hawkins \& Johnston, 1988). To investigate the possibility that the expression of melC (another gene required for melanin production) was also oxygen-sensitive, a fusion between melC and a reporter gene was constructed. So that the activity of melC in the bacteria present in nodules could also be examined, a melC-uidA fusion was constructed. The reporter gene uidA codes for $\beta$-glucuronidase (GUS) (Novel \& Novel, 1972), which can be assayed histochemically both in free-living bacterial cultures and in 
plant tissue due to the very low background levels in both rhizobia (unpublished) and eukaryotic organisms. $\beta$-Glucuronidase is a hydrolase that catalyses the cleavage of a wide variety of $\beta$-glucuronides.

To construct the appropriate fusion, pIJ1651 was mutagenized with Tn3-uidA. This is a Tn3-based transposon containing the uid $A$ gene for glucuronidase production which requires for its expression transcriptional read-through from the gene into which it is inserted. Selection for a melC-uidA fusion was made by screening for loss of the ability of the pIJ1651 derivatives to complement strain $4292 \mathrm{melC}:: \mathrm{Tn} 5$ for melanin production. One such mutant derivative, pIJ1758, was identified. The Tn3-uidA insertion within this plasmid mapped close to the location of $\mathrm{Tn} 5$ in melC in pIJ1745.

Strains $4292 \mathrm{melC}:: \operatorname{Tn} 5 / \mathrm{pIJ} 1758$ and 4292 were inoculated in duplicate into $10 \mathrm{ml}$ liquid $\mathrm{Y}$ medium (supplemented with succinate and sodium glutamate) and a sample of each was incubated at $28{ }^{\circ} \mathrm{C}$ for $48 \mathrm{~h}$ under $20 \%$ or $3 \%$ oxygen. The samples were then assayed for $\beta$-glucuronidase activity. The $\beta$-glucuronidase activity obtained from the $4292 \mathrm{melC}:: \mathrm{Tn} 5 / \mathrm{pIJ} 1758$ culture incubated at $20 \%$ oxygen was 54 units; that obtained from an equivalent culture incubated at $3 \%$ oxygen was 125 units. The wild-type strain had 40 units of activity when grown under either condition. These results indicated that the expression of the melC-uidA fusion is enhanced in microaerobic conditions.

The melC-uidA fusion, present in pIJ1758, was introduced into $R$. $l$. bv. viciae strain $8401 \mathrm{pRL} 1 \mathrm{JI}$. This strain is isogenic to $R$. $l$. bv. phaseoli except that it contains the Sym plasmid pRL1JI which specifies the ability to nodulate peas, rather than pRP2JI, the Sym plasmid of bv. phaseoli. The fusion was not introduced into the genome of bv. phaseoli itself because pPH1JI, the plasmid that was used to eliminate the Tn-marked recombinant plasmid pIJ1758, is itself detrimental to nodulation and $\mathrm{N}_{2}$ fixation on Phaseolus beans, the host of this biovar (F.K.L.H., unpublished) but does not delay nodulation by bv. viciae on peas. Following marker exchange, it was found that the $8401 \mathrm{pRL} 1 \mathrm{JI}$ melC::Tn3 uid $A$ mutant was, as expected, $\mathrm{Mel}^{-}$and slow-growing compared to the wild-type strain 8401 pRL1JI on $\mathrm{Y}$ medium supplemented with either succinate as the $C$ source or nitrate as the $\mathrm{N}$ source.

When inoculated onto peas, strain $8401 \mathrm{pRL} 1 \mathrm{JI}$ melC::Tn3-uidA/pPH1JI formed nodules but they were delayed in their appearance by approximately one week. Eventually some of the nodules became pink (pink nodules indicate that $\mathrm{N}_{2}$ fixation is taking place); three weeks after inoculation, each plant contained approximately $50 \%$ green nodules and $50 \%$ pink nodules. Acetylene reduction tests on individual nodules of each type confirmed that the pink and green nodules were, respectively, $\mathrm{Fix}^{+}$and $\mathrm{Fix}^{-}$. Green and pink nodules were individually crushed and bacteria from within the nodules were isolated. Bacteria isolated from pink nodules were sensitive to ampicillin (specified by Tn3-uidA) and were no longer slow-growing on $\mathrm{Y}$ medium supplemented either with succinate and sodium glutamate or with glucose and sodium nitrate. Thus it is apparent that these $\mathrm{Fix}^{+}$nodules contain bacteria that have lost the transposon and have reverted for the mutant phenotypes. In contrast, bacteria isolated from green nodules retained the original phenotype, i.e. they were ampicillin resistant, and slow-growing on minimal medium containing succinate as the $\mathrm{C}$ source or nitrate as the $\mathrm{N}$ source. All the bacteria isolated from both the pink and green nodules were gentamicin resistant (specified by $\mathrm{pPH} 1 \mathrm{JI}$ ) and streptomycin resistant (specified by $8401 \mathrm{pRL} 1 \mathrm{JI})$.

To examine the expression of $R$. l. bv. viciae melC within the nodule, pink and green nodules were sectioned and stained for glucuronidase activity, using 5 -bromo-4-chloro-3-indolyl $\beta$-D-glucuronidase as the histochemical substrate. Blue staining, indicative of glucuronidase activity, of structures which may have been infection threads was observed in some sections from green nodules, indicating melC-uidA transcription in these areas; no staining was observed in pink nodules (not shown).

\section{Discussion}

Random mutagenesis of plasmid pIJ1651 revealed a gene $(\mathrm{melC})$ which is required for melanin production and for the ability of the bacteria to grow normally with succinate as $\mathrm{C}$ source and nitrate as $\mathrm{N}$ source. A mutation in melC resulted in Fix- strains when inoculated onto peas. The melC mutations were located approximately $5 \mathrm{~kb}$ downstream of $n f r X$ and restriction analysis of the melC-uidA mutation indicates that the transcription of melC-uidA is in the same orientation as $n f r X$ (Hawkins, 1989). Since Tn 5 insertions in $n f r X$ do not abolish melanin production, nor do they affect growth or symbiotic $\mathrm{N}_{2}$ fixation, it is unlikely that $n f r X$ and $m e l C$ are in the same transcriptional unit (F.K.L.H., unpublished).

The inability of the $R$. l. bv. phaseoli melC mutant strain to produce melanin could be overcome by overexpression of $\mathrm{melA}$ either by cloning $\mathrm{melA}$ itself or by over-expressing it through introduction of multi-copy nif $A$ (Hawkins \& Johnston, 1988). One possible explanation for the $\mathrm{Mel}^{-}$phenotype of the $R$. l. bv. phaseoli melC mutant strain is that melC is regulatory; this was tested by investigating the transcription of a melA-lacZ 
fusion in a melC mutant background. Transcription of melA was unaffected in a melC mutant compared to that in the wild-type under the conditions tested, indicating that the $\mathrm{Mel}^{-}$phenotype was not due to lack of expression of melA. The 'link' between the four observed phenotypes caused by melC mutations is unclear. To our knowledge, there is no common step that is involved in (a) $\mathrm{N}_{2}$ fixation ability, (b) melanin production, (c) growth on succinate, and $(d)$ growth on nitrate. It is significant, however, that $n i f A$-activated genes, succinate utilization and nitrate utilization in $R$. meliloti are all affected by mutations in $n t r A$, which encodes an essential sigma factor for $\mathrm{N}_{2}$ fixation (Ronson et al., 1987). There is no direct evidence that melC corresponds to $n$ tr $A$, although there are certain similarities in the phenotypes of $n t r A$ and melC mutant strains.

The Fix ${ }^{-}$phenotype of strain $8401 \mathrm{pRL} 1 \mathrm{JI}$ melC::Tn3 gave a high incidence of revertants, i.e. $\mathrm{Fix}^{+}$nodules, indicating that the Tn3-uidA insertion in melC may be unstable. Staining of nodules for glucuronidase activity to detect expression of the melC-uidA fusion indicated that the melC gene is active in the infection thread. Staining may have taken place only in the infection thread and not in the bacteroids either because melC is only active in the former or because the melC mutation prevented the differentiation of the bacteria into bacteroids. An alternative staining strategy to reveal root nodule morphology and the presence or absence of bacteroids could be used to differentiate between these possibilities.

This work on melC indicates that it is a gene intrinsic to many aspects of symbiotic $\mathrm{N}_{2}$ fixation. Further detailed investigation is required to pinpoint its exact function but the indications are that it promises to be an influential and multi-faceted gene.

This work was supported by the Agricultural \& Food Research Council of Great Britain. We are grateful to Tassos Economou and Allan Downie for useful discussions and to Ethan Signer for providing Tn3-uidA.

\section{References}

Bagdasarian, M., Lurz, R., Ruckert, B., Franklin, F. C. H., Bagdasarian, M. M., Frey, J. \& Timmis, K. N. (1981). Specificpurpose plasmid cloning vectors. II. Broad host range, high copy RSF1010-derived vectors, and a host-vector system for gene cloning in Pseudomonas. Gene 16, 237-247.

BERINGER, J. E. (1974). R. factor transfer in Rhizobium leguminosarum. Journal of General Microbiology 84, 188-198.

Beynon, J. L., Beringer, J. E. \& Johnston, A. W. B. (1980). Plasmids and host range in Rhizobium leguminosarum and Rhizobium phaseoli. Journal of General Microbiology 120, 421-429.

BorthakuR, D., Lamb, J. W. \& Johnston, A. W. B. (1987). Identification of two classes of Rhizobium phaseoli genes required for melanin synthesis, one of which is required for nitrogen fixation and activates the transcription of the other. Molecular and General Genetics 207, 156-160.

Downie, J. A., Hombrecher, G., MA, Q.-S., KNIGHT, C. D., Wells, B. \& Johnston, A. W. B. (1983). Cloned nodulation genes of Rhizobium leguminosarum determine host range specificity. Molecular and General Genetics 190, 359-365.

FigURSKI, D. H. \& HelinSKI, D. R. (1979). Replication of an origincontaining derivative of plasmid RK2 dependent on a plasmid function provided in trans. Proceedings of the National Academy of Science of the United States of America 76, 1648-1652.

Friedman, A. M., Long, S. R., Brown S. E., Buikema, W. J. \& Ausubel, F. M. (1982). Construction of a broad host range cosmid cloning vector and its use in the genetic analysis of Rhizobium mutants. Gene 18, 289-296.

HaWkins, F. K. L. (1989). Studies on the nif A gene of Rhizobium leguminosarum. $\mathrm{PhD}$ thesis, University of East Anglia.

Hawkins, F. K. L. \& Johnston, A. W. B. (1988). Transcription of a Rhizobium leguminosarum biovar phaseoli gene needed for melanin synthesis is activated by nif $A$ of Rhizobium and Klebsiella pneumoniae. Molecular Microbiology 2, 331-337.

JEFFERSEN, R. A., BURGESS, S. M. \& HIRSH, D. (1986). $\beta$-Glucuronidase from Escherichia coli as a gene-fusion marker. Proceedings of the National Academy of Sciences of the United States of America 83, 8447-8451.

Jeffersen, R. A., Kavanagh, T. A. \& Bevan, M. W. (1987). GUS fusions: $\beta$-glucuronidase as a sensitive and versatile gene fusion marker in higher plants. EMBO Journal 6, 3901-3907.

Johnston, A. W. B., Beynon, J. L., Buchanan-Wollaston, A. V., Setchell, S. M., Hirsch, P. R. \& Beringer, J. E. (1978). High frequency transfer of nodulation ability between strains and species of Rhizobium. Nature, London 276, 634-636.

Johnston, A. W. B., Hombrecher, G., Brewin, N. J. \& CoOper, M. C. (1982). Two transmissible plasmids in Rhizobium leguminosarum strain 300. Journal of General Microbiology 128, 85-93.

LAMB, J. W., Downie, J. A. \& Johnston, A. W. B. (1985). Cloning of the nodulation (nod) genes of Rhizobium phaseoli and their homology to $R$. leguminosarum nod genes. Gene 34, 235-241.

LAMb, J. W., Hombrecher, G. \& Johnston, A. W. B. (1982). Plasmid determined nodulation and nitrogen fixation abilities in Rhizobium phaseoli. Molecular and General Genetics 186, 449-452.

LoNG, S. R. (1989). Rhizobium-legume nodulation: life together in the underground. Cell 56, 203-214.

Maniatis, T., Fritsch, E. F. \& Sambrook, J. (1982). Molecular Cloning, a Laboratory Manual. Cold Spring Harbor, NY: Cold Spring Harbor Laboratory.

Merrick, M., Filser, M., Kennedy, C. \& Dixon, R. (1978). Polarity of mutations induced by insertion of transposons $\operatorname{Tn} 5, \operatorname{Tn} 7$ and $\operatorname{Tn} 10$ into the nif gene cluster of Klebsiella pneumoniae. Molecular and General Genetics 165, 103-111.

Miller, J. H. (1972). Experiments in Molecular Genetics. Cold Spring Harbor, NY: Cold Spring Harbor Laboratory.

Newton, J. W., Wilsen, P. W. \& Burris, R. H. (1953). Direct demonstration of ammonia as an intermediate in nitrogen fixation by Azotobacter. Journal of Biological Chemistry 204, 445-451.

Novel, G. \& Novel, M. (1973). Mutants d'Escherichia coli K12 affectés pour leur croissance sur methyl $\beta$-D-glucuronide: localisation du gene de structure de la $\beta$-D-glucuronidase (uidA). Molecular and General Genetics 120, 319-335.

Ronson, C. W., Nixon, B. T., Albright, L. M. \& Ausubel, F. M. (1987). Rhizobium meliloti ntrA mutants fail to utilize succinate as a carbon source. Journal of Bacteriology 169, 2424-2431.

Rossen, L., Shearman, C. A., Johnston, A. W. B. \& Downie, J. A. (1985). The nodD gene of Rhizobium leguminosarum is autoregulatory and in the presence of plant exudate induces the $\operatorname{nod} A, B$ and $C$ genes. EMBO Journal 4, 3369-3373.

Ruvkun, G. B. \& Ausubel, F. M. (1981). A general method for sitedirected mutagenesis in prokaryotes. Nature, London 289, 85-88.

Santero, E., Toukdarian, A., Humphrey, R. \& KenNedy, C. (1988). Identification and characterization of two nitrogen fixation regulatory regions, nif $A$ and $n f r X$, in Azotobacter vinelandii and Azotobacter chroococum. Molecular Microbiology 2, 303-314. 
Stachel, S. E., Gynheung, A., Flores, C. \& Nester, E. W. (1985). A $\operatorname{Tn} 3$ lac $Z$ transposon for the random generation of $\beta$-galactosidase gene fusions: application to the analysis of gene expression in Agrobacterium. EMBO Journal 4, 891-898.

Toukdarian, A. \& KenNedY, C. (1986). Regulation of nitrogen metabolism in Azotobacter vinelandii: isolation of $n t r$ and $g \ln A$ genes and construction of ntr mutants. EMBO Journal 6, 399-407.

WoOD, W. B. (1966). Host specificity of DNA produced by $E$. coli bacterial mutation affecting the restriction and modification of DNA. Journal of Molecular Biology 16, 118-133. 